\title{
Variation in glomalin in soil profiles and its association with climatic conditions, shelterbelt characteristics, and soil properties in poplar shelterbelts of Northeast China
}

\author{
Qiong Wang ${ }^{1,2,3} \cdot$ Wenjie Wang ${ }^{1,2} \cdot$ Zhaoliang Zhong $^{1} \cdot$ Huimei Wang ${ }^{1} \cdot$ \\ Yujie $\mathbf{F u}^{1}$
}

Received: 2 August 2018/Accepted: 15 September 2018/Published online: 19 March 2019

(C) The Author(s) 2019

\begin{abstract}
Glomalin-related soil protein (GRSP) sequesters large amounts of carbon and plays important roles in maintaining terrestrial soil ecosystem functions and ecological restoration; however, little is known about GRSP variation in 1-m soil profiles and its association with stand characteristics, soil properties, and climatic conditions, hindering GRSP-related degraded soil improvement and GRSP evaluation. In this study, we sampled soils from
\end{abstract}

Project funding: This study was supported financially by China's National Foundation of Natural Sciences (41877324, 41730641), Fundamental Research Funds for the Central Universities (2572017DG04, 2572017EA03), and 13-5 Key Research and Development Project from China Ministry of Science and Technology (2016YFA0600802) and Heilongjiang Province for Distinguished Young Scholars (JC201401).

The online version is available at http://www.springerlink.com

Corresponding editor: Chai Ruihai.

Electronic supplementary material The online version of this article (https://doi.org/10.1007/s11676-019-00909-w) contains supplementary material, which is available to authorized users.

Wenjie Wang

wjwang225@hotmail.com

$\triangle$ Huimei Wang

whm0709@hotmail.com

1 Northeast Forestry University, Harbin 150040, People's Republic of China

2 Northeast Institute of Geography and Agroecology, Chinese Academy of Sciences, Changchun 130102, People's Republic of China

3 University of Chinese Academy of Sciences, Beijing 100049, People's Republic of China 1-m profiles from poplar (Populus spp.) shelterbelts in Northeast China. GRSP contents were 1.8-2.0 times higher in the upper $40 \mathrm{~cm}$ soil layers than at $40-100 \mathrm{~cm}$. GRSP-related soil organic carbon (SOC) sequestration in deeper soil layers was $\sim 1.2$ times higher than in surface layers. The amounts of GRSP-related nutrients were similar throughout the soil profile. A redundancy analysis showed that in both surface and deeper layers, soil properties $(\mathrm{pH}$, electrical conductivity, water, SOC, and soil nutrients) explained the majority of the GRSP variation (59.5-84.2\%); the second-most-important factor in GRSP regulation was climatic conditions (temperature, precipitation, and altitude), while specific shelterbelt characteristics had negligible effects $(<5 \%)$. Soil depth and climate indirectly affected GRSP features via soil properties, as manifested by structural equation model analysis. Our findings demonstrate that GRSP is important for carbon storage in deep soils, regardless of shelterbelt characteristics. Future glomalin assessments should consider these vertical patterns and possible regulating mechanisms that are related to soil properties and climatic changes.

Keywords Soil depth · Glomalin-related soil protein (GRSP) - Soil organic carbon storage · Climate change · Soil improvement

\section{Introduction}

Glomalin-related soil protein (GRSP) is a stable and persistent glycoprotein that is produced in copious quantities by arbuscular mycorrhizal fungi (Gillespie et al. 2011). GRSP is considered an essential component of the soil organic carbon (SOC) pool in terrestrial ecosystems (Wright et al. 
1996; Jia et al. 2016) and acts as a soil conditioner by improving fertility, aeration, water holding capacity, nutrient levels, and plant productivity (Fokom et al. 2012). Many GRSP-related studies have focused on the surface soil due to the assumption that a stable state is reached in deeper soil layers over time (Wu et al. 2012; Zhang et al. 2015; Yang et al. 2017; Wang et al. 2018a), despite evidence contradicting this (Harrison et al. 2011). Limited information is available regarding GRSP variation in vertical soil profiles in forests (Wang et al. 2017a). Vertical soil sampling at both surface and deeper soil layers in a wide range of regions should be carried out to determine the importance of GRSP in deep soil carbon and nutrient cycling (Wang et al. 2017a).

There are over 6.67 million ha of poplar plantations in China, which is world's greatest use of poplar for afforestation (Wu and Wang 2016). Poplar is one of the main genera used in farmland shelterbelts in north eastern China (Zhao 2002; Wu et al. 2018; Yang et al. $2018 \mathrm{a}$, b) to protect soil against wind erosion, improve soil fertility, and protect food products (Deng et al. 2009; Wu and Wang 2016; Wang et al. 2017b, c; Ge et al. 2018; Jha 2018). Because of the importance of GRSP in improving degraded soil (Wright and Upadhyaya 1996; Wang et al. 2015), a comprehensive understanding of GRSP variation in northeastern China and its relationship with soil properties, shelterbelt characteristics, and climatic conditions could facilitate effective management aimed at improving soil quality (Wang et al. 2015, 2017a).

In this study, we hypothesize that GRSP contributions to SOC accumulation and nutrient storage depend on soil depth, and that GRSP features are significantly affected by one or more of the following: soil properties, shelterbelt characteristics, and/or climatic conditions. In particular, we aim to investigate: (1) the variation in GRSP features in soil layers up to a 1-m depth and whether other soil properties exhibit similar vertical variation; and, (2) the effects of soil properties, shelterbelt characteristics, and climatic conditions on these GRSP patterns as well as differences between deep and surface soils. The data will support the evaluation of GRSP in poplar shelterbelts and the importance of deep soil.

\section{Materials and methods}

The six study regions were on the Songnen Plain, northeastern China (Table 1). The soil type was typical black soil, characterized as cambosols in Dumeng, chernozem (agrosols) in Fuyu and Lanling, solonetz (alkalic halosols) in Zhaodong and Zhaozhou, and phaeozem (isohumosols) in Mingshui. Climatic conditions shown in Table 1. Detailed information can also be found in previous publications (Wang et al. 2015, 2017a).

Field surveys were conducted in June and August, 2012. In each of the six locations (Dumeng, Fuyu, Lanling, Mingshui, Zhaodong, and Zhaozhou), 12 sample plots were established in poplar shelterbelts. Soil samples were obtained from 1-m deep soil profiles at five depths separated by $20 \mathrm{~cm}$. A total of 360 soil samples (6 locations $\times 12$ plots $\times 5$ depths) were collected using the stratified random sampling method. Soil samples were drawn using a $100 \mathrm{~cm}^{3}$ cutting ring driven into the soil with a plastic hammer. An exact $400-\mathrm{cm}^{3}$ portion of intact soil was stored in cloth pouches, transported to the laboratory, homogenized, and air-dried to a constant weight. Soil bulk density (BD) was calculated as the ratio between dry soil mass and soil volume $\left(400 \mathrm{~cm}^{3}\right)$. Vegetation, stones, rock fragments, and roots were removed from the soil samples. The samples were then milled and sieved $(0.25 \mathrm{~mm})$ for further analyses.

Shelterbelt parameters were surveyed: diameter at breast height (DBH), age, tree density, height, shelterbelt width, distance between shelterbelts and farmlands, and ditch depth and width. Ditches were usually dug by local farmers to avoid the negative effects of poplar on crop production, and many of the shelterbelt forests had ditches. The distance between shelterbelts and farmlands was recorded to evaluate a possible influence. Stand age was recorded by interviewing local farmers and forest administrators. The main crop on the neighboring farmlands was corn, and the previous crops were corn and soybean.
Table 1 Basic information on six sampling locations

\begin{tabular}{llllll}
\hline Sampling location & Longitude & Latitude & MAT $\left({ }^{\circ} \mathrm{C}\right)$ & MAP $(\mathrm{mm})$ & Altitude $(\mathrm{m})$ \\
\hline Dumeng & $124^{\circ} 19^{\prime}-125^{\circ} 12^{\prime} \mathrm{E}$ & $45^{\circ} 46^{\prime}-46^{\circ} 55^{\prime} \mathrm{N}$ & 3.1 & 421 & 147 \\
Fuyu & $124^{\circ} 48^{\prime}-126^{\circ} 51^{\prime} \mathrm{E}$ & $45^{\circ} 37^{\prime}-45^{\circ} 40^{\prime} \mathrm{N}$ & 3 & 441 & 157.9 \\
Lanling & $125^{\circ} 13^{\prime}-126^{\circ} 18^{\prime} \mathrm{E}$ & $45^{\circ} 13^{\prime}-45^{\circ} 18^{\prime} \mathrm{N}$ & 4.4 & 481 & 381.3 \\
Mingshui & $125^{\circ} 41^{\prime}-126^{\circ} 42^{\prime} \mathrm{E}$ & $45^{\circ} 08^{\prime}-45^{\circ} 43^{\prime} \mathrm{N}$ & 2.9 & 480 & 258.7 \\
Zhaodong & $125^{\circ} 22^{\prime}-126^{\circ} 22^{\prime} \mathrm{E}$ & $45^{\circ} 10^{\prime}-46^{\circ} 20^{\prime} \mathrm{N}$ & 3.8 & 467 & 165.9 \\
Zhaozhou & $124^{\circ} 55^{\prime}-125^{\circ} 12^{\prime} \mathrm{E}$ & $45^{\circ} 41^{\prime}-45^{\circ} 49^{\prime} \mathrm{N}$ & 3.5 & 450 & 146.7 \\
\hline
\end{tabular}

MAT mean annual temperature, MAP mean annual precipitation 


\section{Soil property determination}

SOC was determined by the potassium dichromate volumetric method by external heating. The semimicro-Kjeldahl method was used to determine total nitrogen $(\mathrm{N})$, and the alkaline hydrolysis diffusion method to determine available $\mathrm{N}$ (AN). Total phosphorus (P) content was measured using the $\mathrm{NaOH}$ fusion-Mo-Sb anti-spectrophotometric method. Available P (AP) was determined by extraction using a $0.05 \mathrm{~N} \mathrm{HCl}-0.025 \mathrm{~N} \mathrm{H}_{2} \mathrm{SO}_{4}$ solution and reaction with a solution of 1-ascorbic acid and $\mathrm{H}_{2} \mathrm{SO}_{4}-$ $\left(\mathrm{NH}_{4}\right)_{6} \mathrm{Mo}_{7} \mathrm{O}_{24}$. Total potassium $(\mathrm{K})$ was measured using the $\mathrm{NaOH}$ fusion-flame spectrometric method. Soil available $\mathrm{K}(\mathrm{AK})$ was extracted with a $1.0-\mathrm{N} \mathrm{NH}_{4} \mathrm{OAc}$ solution and measured using a flame photometer. All of these analyses were conducted according to Bao (2000).

Soil $\mathrm{pH}$ was determined in a $1.0 \mathrm{-g}$ suspension of the sample in $5 \mathrm{~mL}$ of deionized water using a Sartorius PB10 acidometer (Sartorius PT-21; Shanghai, China). An electrical conductivity (EC) meter (DDS-307; Shanghai Precision Scientific Instruments Co., Ltd., Shanghai, China) determined EC in the same suspension. Soil water (percent) was determined according to: [(Fresh weight - Dry weight)/Dry weight] $\times 100$ (Wang et al. 2011)

\section{GRSP determination}

GRSP extraction from the soil and its measurement was performed by slightly modifying the method of Wright and Upadhyaya (1998). For the easily-extractable GRSP (EEG), $0.5 \mathrm{~g}$ of each sample was suspended in $4.0 \mathrm{~mL}$ of $20 \mathrm{mmol} \mathrm{L}{ }^{-1}$ sodium citrate $(\mathrm{pH}=7.0)$ and autoclaved for $30 \mathrm{~min}$ at $121{ }^{\circ} \mathrm{C}$. Total GRSP (TG) was removed from $0.1 \mathrm{~g}$ samples with $4.0 \mathrm{~mL}$ of $50 \mathrm{mmol} \mathrm{L}^{-1}$ sodium citrate $(\mathrm{pH}=8.0)$ and autoclaved for $1 \mathrm{~h}$ at $121^{\circ} \mathrm{C}$. The supernatants were separated by centrifugation at $4000 \mathrm{rpm}$ for $6 \mathrm{~min}$ and collected. For TG, each sample was repeatedly autoclaved for $30 \mathrm{~min}$ at $121{ }^{\circ} \mathrm{C}$ until the typical reddish-brown GRSP color faded from the supernatant. All extracts from each soil sample were then pooled. The Bradford assay using bovine serum albumin as a reference was used to determine the GRSP content in the extracts.

Usually TG is extracted from $1.0 \mathrm{~g}$ of soil in $8 \mathrm{~mL}$ of extractant to maintain the ratio of soil to extract as 1:8 (w/ v), and autoclaved for $60-450 \mathrm{~min}$ at $121{ }^{\circ} \mathrm{C}$. Janos et al. (2008) evaluated a variety of ratios $(1: 8,1: 16,1: 24$, and 1:32) for extracting TG and did not observe any obvious differences, suggesting that equal volumes of extraction solution to extract TG can be used in the same study. The soil in this region is typical black soil, and our pre-experiment showed that a low solution to soil ratio (1:8) made it difficult to observe the reddish-brown fading endpoint.
Therefore, a ratio of 1:40 (w/v) was used to accelerate the extraction procedure $\left(30 \mathrm{~min}\right.$ at $\left.121^{\circ} \mathrm{C}\right)$.

The GRSP features investigated were: TG, EEG, TG-C/ SOC, EEG-C/SOC, EEG-N/N, EEG-P/P, TG-N/N, TG-P/ $\mathrm{P}$, and EEG/TG. The C (39.7\%), P (0.6\%), N (3.8\%), and K $(6.6 \%)$ contents in purified GRSP were obtained from a previous publication (Wang et al. 2015) to calculate the C, $\mathrm{P}, \mathrm{N}$, and $\mathrm{K}$ contents in GRSP, which were then used to calculate the other features. The GRSP contribution to $\mathrm{K}$ was only $0.6 \%$ for TG and only $0.07 \%$ for EEG, so these were not included in the analysis.

\section{Data analysis}

A multivariate analysis of variance and Duncan's multiple range test were used to analyze variations in GRSP features and soil properties at different soil depths. Redundancy analysis (RDA) and structural equation modeling (SEM) were used to investigate associations between GRSP features and various soil properties, shelterbelt characteristics, and climatic conditions, as well as to evaluate differences between deep and surface soils.

A partition analysis of RDA-related variation was used to analyze the relative contributions of climatic conditions, shelterbelt characteristics, and soil properties to GRSP variation. RDA-related ordination and variation partitioning analyses were conducted using Canoco 5.0. To analyze the variation between the deep and surface soil layers, a conditional term effect in the RDA variation partitioning was used to evaluate soil at $40-100 \mathrm{~cm}$ (deep soil) and 0-40 cm (surface soil).

SEM was applied to identify indirect and direct effects of soil depth, soil properties, shelterbelt characteristics, and climatic conditions on the GRSP features. A principal component analysis (PCA) was used to extract information from the data regarding climatic conditions, shelterbelt characteristics, and soil properties in order to elucidate the complicated associations found in the SEM analysis. The threshold for components in the PCA was an eigenvalue greater than 1. This analysis was conducted in SPSS 22.0 and SPSS AMOS 22.0 (IBM, Armonk, NY, USA).

\section{Results}

\section{Differences in GRSP features among soil depths}

GRSP (TG and EEG) contents decreased linearly from the $0-20$ to the $80-100 \mathrm{~cm}$ layers $(p<0.01)$ (Table 2$)$. The mean EEG at $0-40 \mathrm{~cm}$ was 1.9 -fold higher than that at 40-100 cm; similarly, TG at 0-40 cm was 1.8 -fold higher than that at $40-100 \mathrm{~cm}$. GRSP-C/SOC increased linearly from the $0-20 \mathrm{~cm}$ layer to the $80-100 \mathrm{~cm}$ layer $(p<0.05)$ 
Table 2 Differences in GRSP features among soil depths and linear regression analysis

\begin{tabular}{|c|c|c|c|c|c|c|c|c|}
\hline \multirow[t]{2}{*}{ Parameters } & \multicolumn{5}{|c|}{ Soil depth $(\mathrm{cm})$} & \multicolumn{3}{|l|}{ Linear changes } \\
\hline & $0-20$ & $20-40$ & $40-60$ & $60-80$ & $80-100$ & Equation & $\mathrm{R}^{2}$ & $p$ \\
\hline EEG $(g / k g)$ & $0.67(0.29) \mathrm{b}$ & $0.56(0.48) b$ & $0.38(0.32) \mathrm{a}$ & $0.33(0.33) \mathrm{a}$ & $0.26(0.24) \mathrm{a}$ & $y=-0.0053 x+0.7025$ & 0.160 & 0.000 \\
\hline TG $(\mathrm{g} / \mathrm{kg})$ & $6.29(2.41) \mathrm{d}$ & $4.51(2.31) \mathrm{c}$ & $3.81(2.63) \mathrm{c}$ & $2.92(2.57) b$ & $2.11(1.68) \mathrm{a}$ & $y=-0.0498 x+6.4163$ & 0.265 & 0.000 \\
\hline EEG-C/SOC & $0.02(0.01) \mathrm{a}$ & $0.02(0.02) \mathrm{a}$ & $0.02(0.01) \mathrm{a}$ & $0.02(0.04) \mathrm{a}$ & $0.03(0.10) \mathrm{a}$ & $y=0.0002 x+0.0124$ & 0.013 & 0.032 \\
\hline TG-C/SOC & $0.15(0.05) \mathrm{a}$ & $0.14(0.06) \mathrm{a}$ & $0.17(0.12) a b$ & $0.18(0.14) a b$ & $0.23(0.34) b$ & $y=0.001 x+0.1245$ & 0.024 & 0.004 \\
\hline EEG-N/N & $0.02(0.01) \mathrm{a}$ & $0.02(0.01) \mathrm{a}$ & $0.02(0.02) \mathrm{a}$ & $0.02(0.02) \mathrm{a}$ & $0.02(0.02) \mathrm{a}$ & $\mathrm{y}=4 \mathrm{E}-05 \mathrm{x}+0.0183$ & 0.003 & 0.309 \\
\hline TG-N/N & $0.17(0.06) \mathrm{a}$ & $0.13(0.05) \mathrm{a}$ & $0.21(0.23) \mathrm{a}$ & $0.17(0.12) \mathrm{a}$ & $0.19(0.19) \mathrm{a}$ & $y=0.0004 x+0.1536$ & 0.006 & 0.160 \\
\hline TG-P/P & $0.10(0.04) \mathrm{a}$ & $0.13(0.24) \mathrm{ab}$ & $0.17(0.26) \mathrm{b}$ & $0.28(0.92) \mathrm{c}$ & $0.12(0.39) a b$ & $\mathrm{y}=0.0009 \mathrm{x}+0.1117$ & 0.003 & 0.422 \\
\hline EEG-P/P & $0.01(0.01) \mathrm{a}$ & $0.01(0.01) \mathrm{a}$ & $0.02(0.02) \mathrm{a}$ & $0.05(0.26) \mathrm{a}$ & $0.01(0.02) \mathrm{a}$ & $\mathrm{y}=0.0002 \mathrm{x}+0.0118$ & 0.002 & 0.290 \\
\hline EEG/TG & $0.12(0.07) \mathrm{a}$ & $0.18(0.36) \mathrm{ab}$ & $0.15(0.15) a b$ & $0.18(0.23) a b$ & $0.25(0.35) \mathrm{b}$ & $y=0.0012 x+0.1142$ & 0.019 & 0.010 \\
\hline
\end{tabular}

Different lowercase letters indicate the differences of the GRSP features among soil depth, statistically significant at $p<0.05$. Number in bracket is standard deviation

Bold value indicates significance of the linear regression at $p<0.05$

(Table 2). GRSP-C/SOC was $\sim 1.2$ times higher in the $40-100 \mathrm{~cm}$ layer than in the $0-40 \mathrm{~cm}$ layer, indicating that the contribution of GRSP to SOC sequestration was much greater in the deeper soil layer. Moreover, EEG-N/N, EEG$\mathrm{P} / \mathrm{P}$, TG-N/N, and TG-P/P exhibited linear increases with soil depth $(p>0.05)$ (Table 2$)$. EEG/TG was 1.3 times higher in the 40-100 cm layer than in the $0-40 \mathrm{~cm}$ layer (Table 2).

\section{Vertical variation in soil properties}

Soil BD was $3.6 \%$ higher in the $60-100 \mathrm{~cm}$ soil layer than in the $0-40 \mathrm{~cm}$ soil layer $(p<0.05)$. Soil water was $1.2-$ fold higher at $0-40 \mathrm{~cm}$ than at $60-100 \mathrm{~cm}$, while the $\mathrm{pH}$ was 0.6 units higher in the $60-100 \mathrm{~cm}$ layer than in the $0-40 \mathrm{~cm}$ layer $(p<0.05)$ (Table 3$)$. Soil EC peaked in the 20-40 cm layer (Table 3). SOC, N, AN, and P were 1.4-2.3 times higher in the $0-40 \mathrm{~cm}$ layer than in the 40-100 cm layer (Table 3). AP and AK peaked in the 0-20 cm layer, while $\mathrm{K}$ was lowest in this layer (Table 3). A regression analysis showed that soil $\mathrm{BD}, \mathrm{pH}$, and $\mathrm{K}$ increased linearly, while soil water, SOC, P, AP, N, AN, and $\mathrm{AK}$ decreased linearly, as soil depth increased (Table 3).

\section{Changes in shelterbelt characteristics}

The ages of the shelterbelts ranged from 3.5 to 60.0 years, with the mean ages at the six locations from 17.1 to 23.7 years (Fig. 1). Over half of the plots (40) were had trees that were 3.5-22.3 years-old. DBH estimates were all within $4.9-53.6 \mathrm{~cm}$, and mean values at the six locations ranged from 19.8 to $28.5 \mathrm{~cm}$ (Fig. 1). Tree heights ranged from 3.8 to $24.0 \mathrm{~m}$, with most within 17.2-20.6 m (19 plots, $26 \%$ of total plots) (Fig. 1).
Tree densities ranged from 8.1 trees/100 $\mathrm{m}^{2}$ to 98.1 trees $/ 100 \mathrm{~m}^{2}$. Regarding mean tree density, the lowest density was 33.1 trees $/ 100 \mathrm{~m}^{2}$ at Dumeng, and the highest was 41.6 trees $/ 100 \mathrm{~m}^{2}$ at Zhaodong (Fig. 1). Average shelterbelt widths at each location ranged from 5.4 to $9.1 \mathrm{~m}$, and the frequency distribution peaked at $5.8-8.6 \mathrm{~m}$ (43\%) (Fig. 1).

Thirty-nine plots (54\%) had no ditches (Fig. 1). Ditch width was $<2.3 \mathrm{~m}$ in 28 plots (39\% of all plots). The narrowest was at Dumeng $(0.08 \mathrm{~m})$, and the widest at Lanling $(1.28 \mathrm{~m})$. Average depths ranged from $0.08 \mathrm{~m}$ at Dumeng to $1.04 \mathrm{~m}$ at Lanling. The frequency distribution showed that $39 \%$ of the plots had a ditch depth of $<1.5 \mathrm{~m}$. With regards to the distance between the shelterbelts and farmlands, $42 \%$ (30 plots) of the plots were $<3.4 \mathrm{~m}$ away, while $58 \%$ (42 plots) were $>3.4 \mathrm{~m}$ away (Fig. 1).

\section{Variation partitioning: differences between deep and surface soil layers}

Specific soil properties (b) explained about $45 \%$ of the GRSP variation (surface, $47.3 \%$; deep, $45.4 \%$ ) in both the deep soil layer $(40-100 \mathrm{~cm})$ and the surface soil layer (0-40 cm) (Fig. 2). Specific shelterbelt characteristics (a) explained a negligible proportion of GRSP variation in the surface (3.9\%) and deep (0.5\%) soil layers (Fig. 2). Moreover, a greater proportion of GRSP variation was explained by specific climatic conditions (c) in the surface soil $(26.8 \%)$ than in the deeper soil $(15.1 \%)$ (Fig. 2). In the surface soil layer, the interaction among climatic conditions, shelterbelt characteristics, and soil properties $(\mathrm{d}+\mathrm{e}+\mathrm{f}+\mathrm{g})$, explained $21.9 \%$ of the GRSP variation, while in the deeper soil, this interaction accounted for $39.0 \%$. In the surface soil layer, the total percentages of the GRSP variation explained by shelterbelt characteristics 


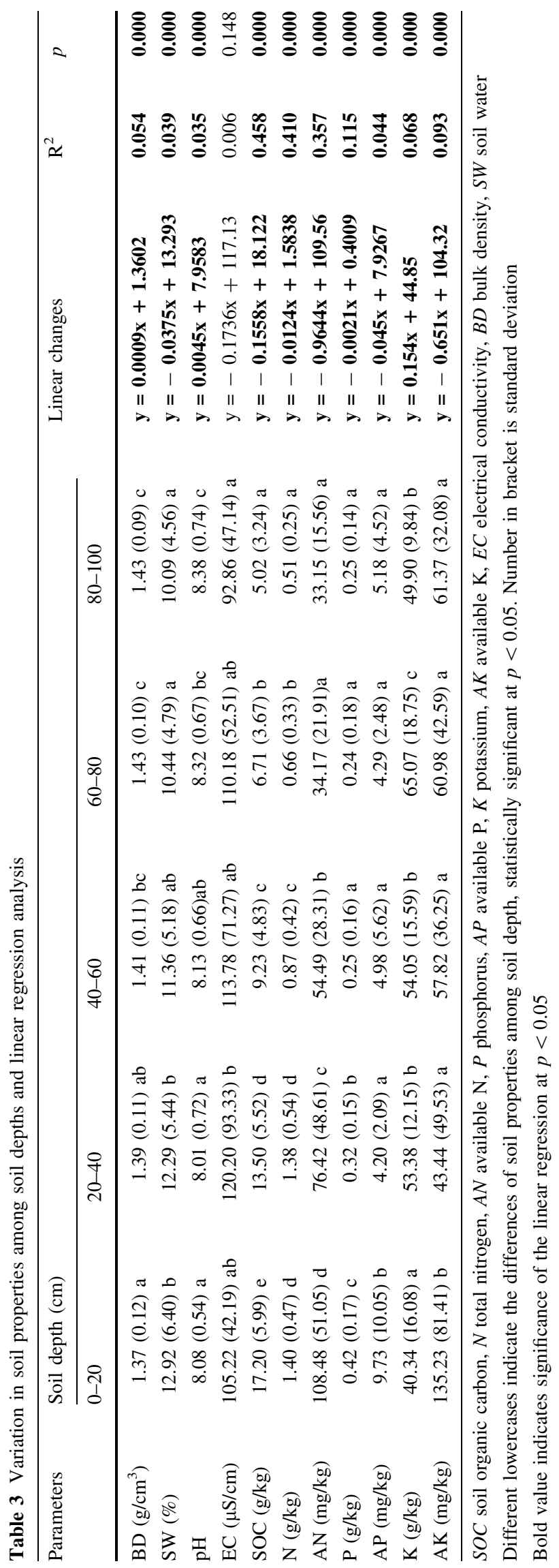

$(\mathrm{a}+\mathrm{d}+\mathrm{g}+\mathrm{f})$, soil properties $(\mathrm{b}+\mathrm{d}+\mathrm{g}+\mathrm{e})$, and climatic conditions $(\mathrm{c}+\mathrm{e}+\mathrm{f}+\mathrm{g})$ were 13.1, 59.5, and $46.7 \%$, respectively, while the contribution of soil properties in the deep soil layer was relatively large (84.2\%) (Fig. 2).

In summary, soil properties were the main determinants of GRSP variation in the surface and deep soil layers, followed by climatic conditions. There was a stronger interaction ( $>2$-fold) between climatic conditions and soil properties in the deep soil layers than in the surface layers, while a stronger interaction was found between climatic conditions and shelterbelt characteristics $(9.7 \%$ vs. $0.2 \%)$ in the surface layer than in the deep layer (Fig. 2).

\section{RDA ordination: the most likely factors responsible for GRSP variation}

In the RDA ordination, two axes explained $55.0 \%$ of the GRSP variation in the surface soil and $43.4 \%$ in the deep soil (Fig. 3). The EEG of the surface soil was negatively related to $\mathrm{pH}$ and MAT, while the EEG of the deep soil was positively related to soil $\mathrm{P}$ and soil water. SOC, N, P, MAP, and shelterbelt widths were strongly related to TG in the surface soil layer, while the relationships were slightly different in the deep soils, i.e., soil AN instead of shelterbelt width played a key role in regulating TG.

In the surface soil, a greater EEG contribution to SOC and nutrients (EEG-C/SOC, EEG-P/P, and EEG-N/N) accompanied higher AP and shelterbelt width values, but lower values for $\mathrm{pH}, \mathrm{MAT}, \mathrm{MAP}, \mathrm{SOC}, \mathrm{N}$, and P. In the deep soil layer, a greater EEG contribution to SOC and nutrients was consistent with the higher $\mathrm{P}$ and soil water and lower MAT and $\mathrm{pH}$ (Fig. 3). The arrow lengths for the contribution of TG to SOC and nutrients (TG-C/SOC, TG$\mathrm{P} / \mathrm{P}$, and TG-N/N) were usually much shorter than those for EEG in both the deep and surface soil layers (Fig. 3). However, TG-N/N in the surface soil had a much greater effect on RDA axis 1 (Fig. 3 and Table S1).

Table 4 shows the relative contributions of various explanatory factors to GRSP variation and the differences between the deep and surface soil layers. In the surface layer, soil properties ( $\mathrm{SOC}, \mathrm{pH}, \mathrm{N}$, and $\mathrm{P}$ ), a climatic factor (MAT), and a shelterbelt-related parameter (ditch width) contributed significantly to GRSP variation $(p<0.05)$. In the deep layer, soil properties (SOC, $\mathrm{pH}, \mathrm{P}$, and soil water), climatic factors (MAP and MAT), and ditch width (shelterbelt characteristic) contributed significantly to GRSP variation $(p<0.05)$. The deep soil samples exhibited greater regulatory effects of soil properties on GRSP variation $(81.1 \%)$ than those in the surface soil samples (75.0\%), while climatic regulation in the deep soil (MAT + MAP, 7.5\%) was similar to that in the surface soil (MAT, $8.4 \%$ ). 


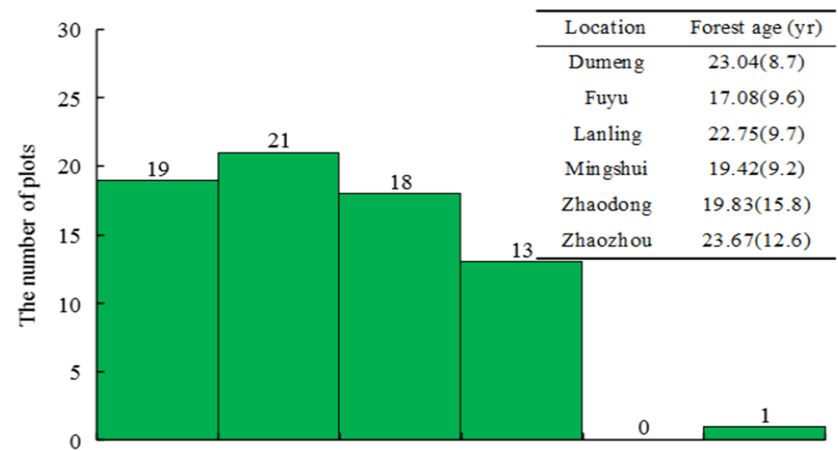

$[3.5,12.9](12.9,22.3](22.3,31.8](31.8,41.2](41.2,50.6](50.6,60.0]$ Forest age (yr)

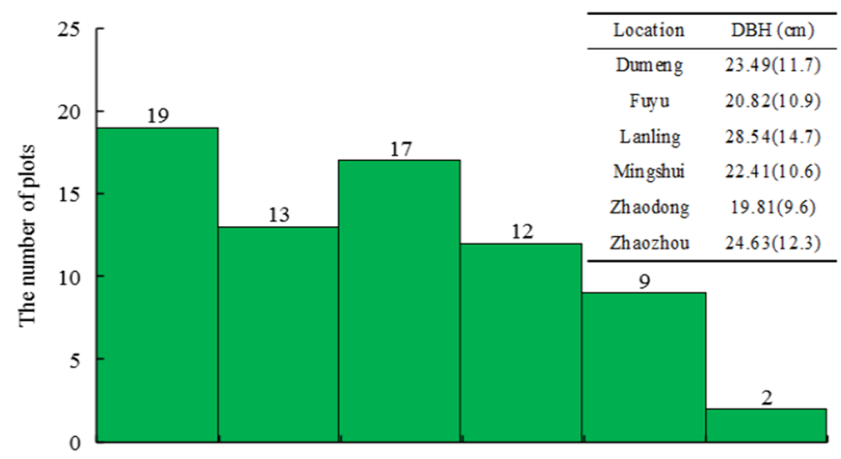

$[4.9,13.0](13.0,21.1](21.1,29.2](29.2,37.4](37.4,45.5](45.5,53.6]$

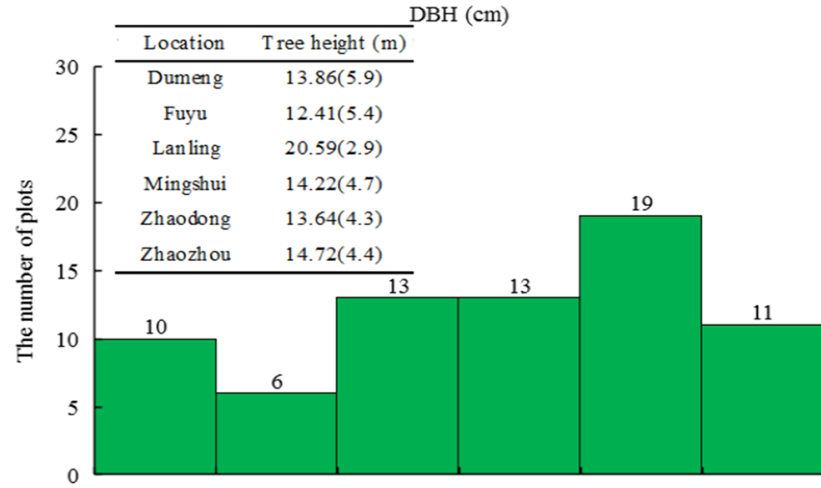

$[3.8,7.2] \quad(7.2,10.5](10.5,13.9](13.9,17.2](17.2,20.6](20.6,24.0]$ Tree height $(\mathrm{m})$

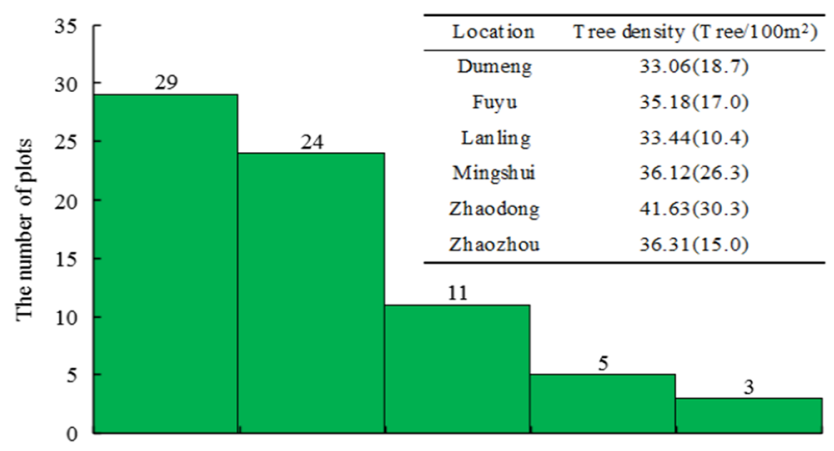

[8.1, 26.1] $(26.1,44.1](44.1,62.1] \quad(62.1,80.1] \quad(80.1,98.1]$ Tree density (Tree $/ 100 \mathrm{~m}^{2}$ )
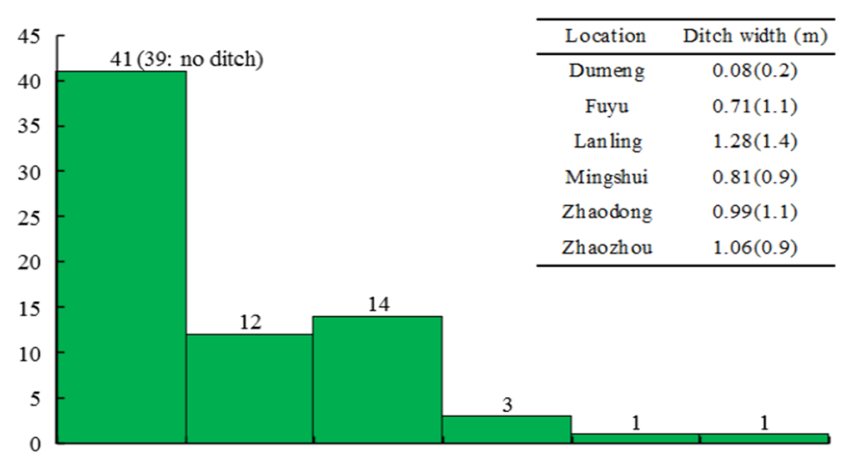

[0.0,0.8] $(0.8,1.6] \quad(1.6,2.3] \quad(2.3,3.1] \quad(3.1,3.9] \quad(3.9,4.7]$

Ditch width (m)
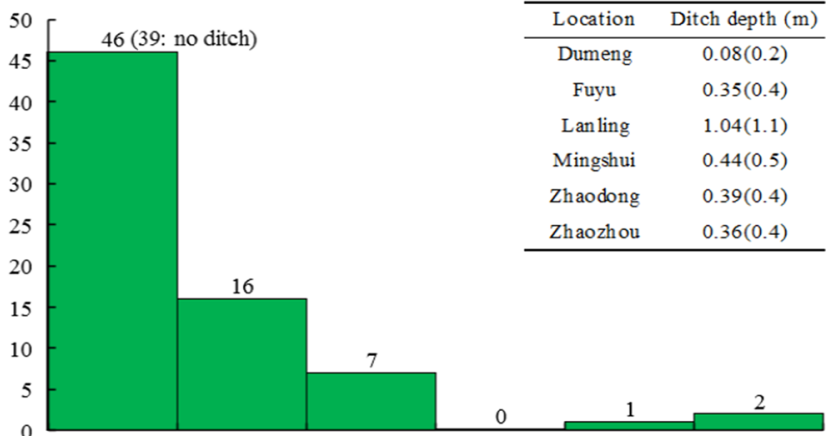

$\left[\begin{array}{lllll}{[0.0,0.5] \quad(0.5,1.0] \quad(1.0,1.5] \quad(1.5,2.0] \quad(2.0,2.5] \quad(2.5,3.0]}\end{array}\right.$

Ditch depth (m)
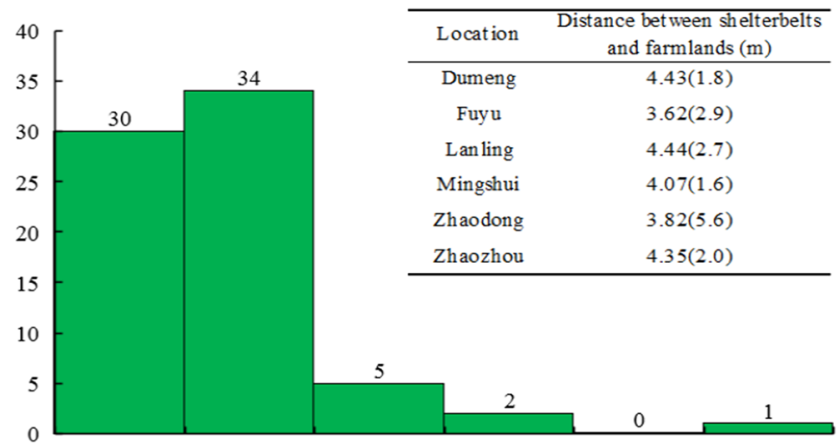

$[0.0,3.4] \quad(3.4,6.7] \quad(6.7,10.1](10.1,13.4](13.4,16.8](16.8,20.2]$ Distance between shelterbelts and farmlands (m)

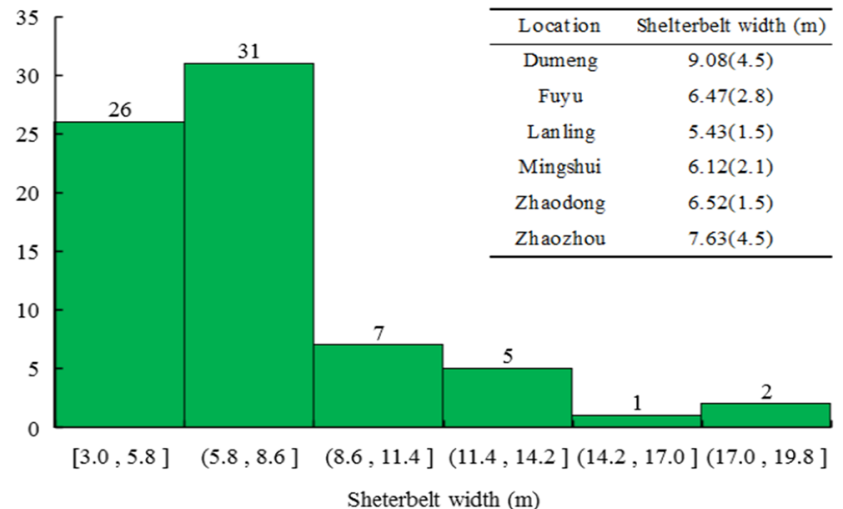

Sheterbelt width (m)

Fig. 1 Frequency distribution of characteristics in poplar shelterbelts. Number in bracket is standard deviation 
(a)

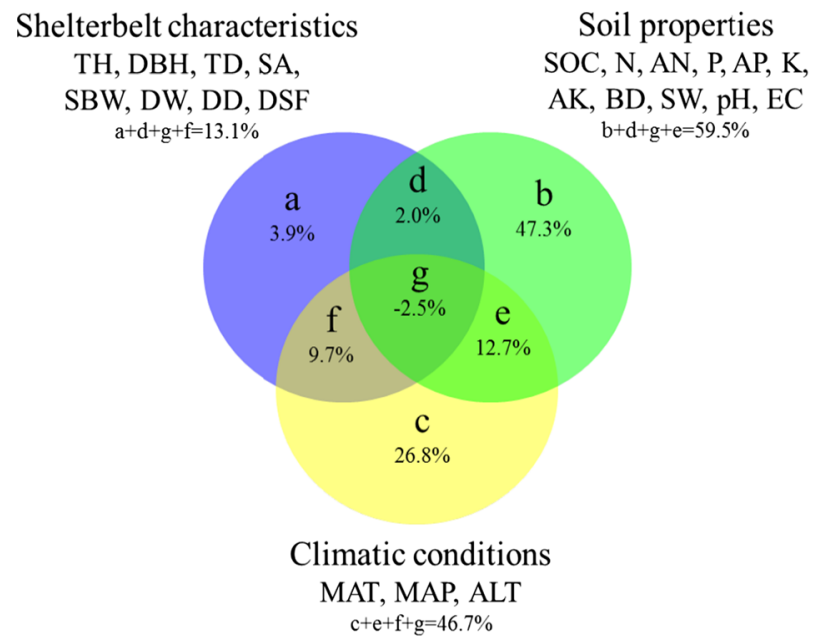

Fig. 2 RDA ordination-based GRSP variation partitioning at the surface soil layers $(0-40 \mathrm{~cm})($ a) and the deep soil layers $(40-100 \mathrm{~cm})$ (b) by selecting 'Var-part-3groups-conditional-effects-tested'. Note: $S O C$ soil organic carbon, $N$ total nitrogen, $A N$ available $\mathrm{N}, P$ phosphorus, $A P$ available $\mathrm{P}, K$ potassium, $A K$ available $\mathrm{K}, E C$

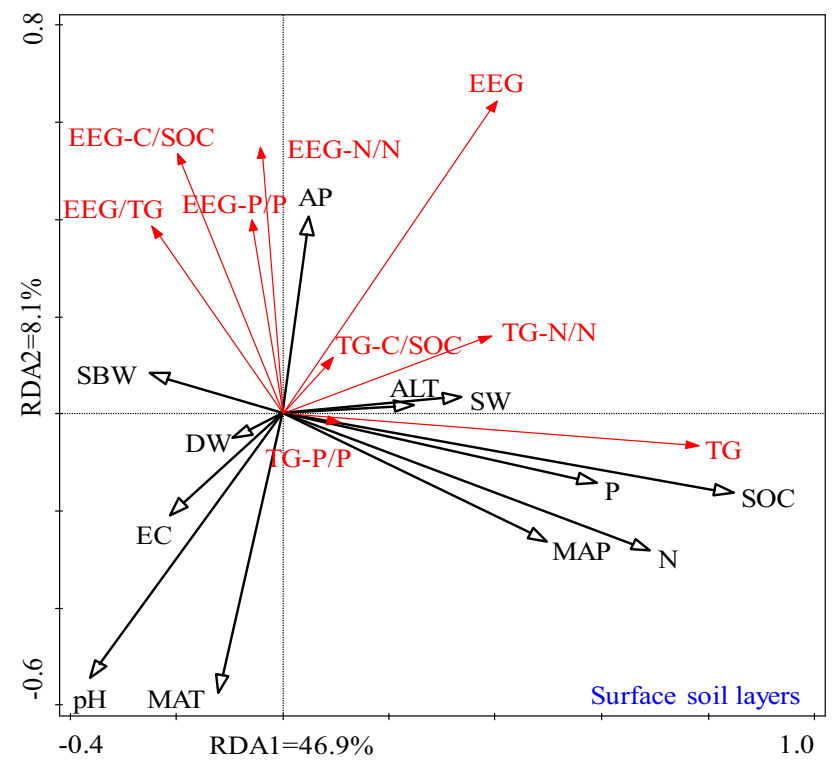

Fig. 3 RDA ordinations through forward selection and comparison between the surface and deep soil layers. Note: SOC Soil organic carbon, $N$ total nitrogen, $A N$ available N, $P$ phosphorus, $A P$ available

\section{SEM analysis of the causal factors for GRSP differences: indirect and direct effects}

In the principal component analysis (PCA), one component extracted $73.6 \%$ of the information from the climatic data (climatic conditions-PCA1) (Fig. 4), which included mean annual precipitation (MAP), altitude, and mean annual (b)

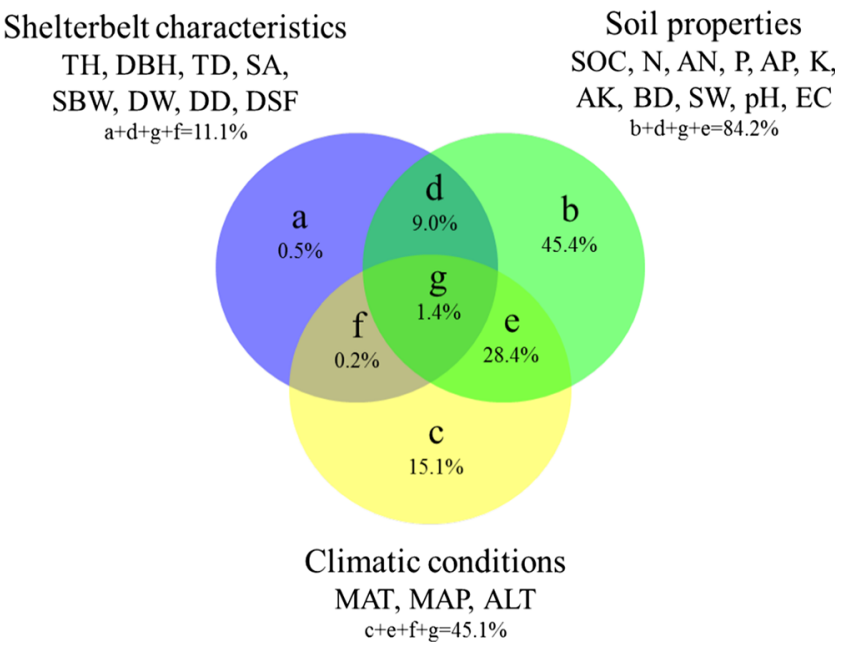

electrical conductivity, $B D$ bulk density, $S W$ soil water, $M A T$ mean annual temperature, $M A P$ mean annual precipitation, $S A$ shelterbelt age, $T H$ tree height, $D B H$ diameter at breast height, $T D$ tree density, $S B W$ shelterbelt width, $D S F$ distance between shelterbelts and farmlands, $D D$ ditch depth, $D W$ ditch width, $A L T$ altitude

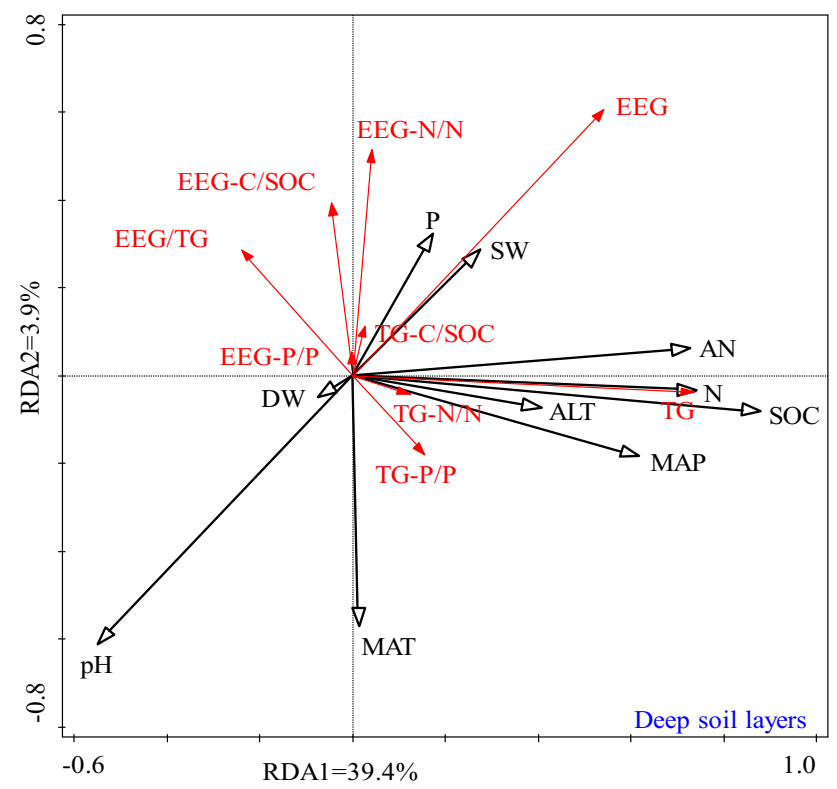

P, EC electrical conductivity, $S W$ soil water, $M A T$ mean annual temperature, $M A P$ mean annual precipitation, $S B W$ shelterbelt width, $D W$ ditch width, $A L T$ altitude

temperature (MAT) (coefficient, 0.36-0.41). With regards to soil properties, two principal components extracted $48.9 \%$ of the information from the raw data (soil properties-PCA1, 35.9\%; soil properties-PCA2, 13.1\%). Soil properties-PCA1 included SOC (coefficient, 0.23), N (coefficient, 0.21), and AN (coefficient, 0.20), while soil properties-PCA2 was mainly based on soil EC (coefficient, 
Table 4 The relative contributions of various explanatory factors to GRSP variation and differences between deep and surface soil layers

\begin{tabular}{|c|c|c|c|c|c|}
\hline Name & Explains \% & Contribution $\%$ & pseudo-F & $P$ & $p(\operatorname{adj})$ \\
\hline \multicolumn{6}{|c|}{ Surface soil layers } \\
\hline SOC & 34.0 & 56.7 & 73.2 & 0.002 & 0.044 \\
\hline pH & 5.5 & 9.1 & 12.7 & 0.002 & 0.044 \\
\hline MAT & 5.1 & 8.4 & 12.8 & 0.002 & 0.044 \\
\hline$N$ & 2.8 & 4.7 & 7.4 & 0.004 & 0.088 \\
\hline$P$ & 2.7 & 4.5 & 7.5 & 0.006 & 0.132 \\
\hline$D W$ & 1.6 & 2.6 & 4.4 & 0.024 & 0.528 \\
\hline MAP & 1.0 & 1.7 & 2.9 & 0.058 & 1 \\
\hline $\mathrm{EC}$ & 1.1 & 1.8 & 3.1 & 0.048 & 1 \\
\hline SBW & 0.9 & 1.5 & 2.7 & 0.072 & 1 \\
\hline SW & 1.0 & 1.7 & 3.1 & 0.060 & 1 \\
\hline ALT & 0.8 & 1.4 & 2.5 & 0.074 & 1 \\
\hline $\mathrm{AP}$ & 0.7 & 1.2 & 2.1 & 0.138 & 1 \\
\hline \multicolumn{6}{|c|}{ Deep soil layers } \\
\hline SOC & 31.0 & 61.9 & 96.0 & 0.002 & 0.044 \\
\hline pH & 4.8 & 9.5 & 15.8 & 0.002 & 0.044 \\
\hline $\mathbf{P}$ & 3.2 & 6.4 & 11.1 & 0.002 & 0.044 \\
\hline MAP & 2.2 & 4.5 & 8.0 & 0.002 & 0.044 \\
\hline$M A T$ & 1.5 & 3.0 & 5.4 & 0.008 & 0.176 \\
\hline$S W$ & 1.6 & 3.3 & 6.2 & 0.010 & 0.220 \\
\hline$D W$ & 1.3 & 2.5 & 4.8 & 0.024 & 0.528 \\
\hline ALT & 0.7 & 1.4 & 2.6 & 0.068 & 1 \\
\hline $\mathrm{N}$ & 0.6 & 1.2 & 2.4 & 0.110 & 1 \\
\hline AN & 0.6 & 1.2 & 2.3 & 0.102 & 1 \\
\hline
\end{tabular}

$S O C$ Soil organic carbon, $N$ total nitrogen, $A N$ available N, $P$ phosphorus, $A P$ available $\mathrm{P}, E C$ electrical conductivity, $S W$ soil water, $M A T$ mean annual temperature, $M A P$ mean annual precipitation, $S B W$ shelterbelt width, $D W$ ditch width, $A L T$ altitude

Bold fonts show the parameters both at $\mathrm{p}$ and $p(\operatorname{adj})<0.05$, while the italics show the parameters at $p<0.05$ but $p(\operatorname{adj})>0.05$

0.55), $\mathrm{pH}$ (coefficient, 0.42), and AP (coefficient, -0.35 ). Three principal components of shelterbelt characteristics included $73.2 \%$ of the information from the raw data. Of these, shelterbelt characteristics-PCA1 contributed $36.2 \%$, shelterbelt characteristics-PCA2 contributed $22.6 \%$, and shelterbelt characteristics-PCA3 contributed $14.4 \%$. Shelterbelt characteristics-PCA1 mainly extracted information from tree age (0.29) and size (DBH, 0.32; height, 0.31), shelterbelt characteristics-PCA2 mainly extracted information from ditch characteristics (ditch depth, 0.45; ditch width, 0.48), and shelterbelt characteristics-PCA3 extracted information from shelterbelt community characteristics (tree density, - 0.44; shelterbelt width, 0.69; distance between shelterbelts and farmlands, - 0.32) (Tables S2 and $\mathrm{S} 3$ ).

As shown in Fig. 4 and Table S4, soil depth directly affected soil properties-PCA1 (SOC and N), while its effect on GRSP variation was indirect via soil properties-PCA1.
The deep soil layer was associated with lower SOC, N, and AN (soil properties-PCA1), leading to lower EEG (0.52) and TG $(0.60)$ but higher EEG-N/N $(-0.45)$, TG-C/SOC $(-0.39)$, TG-N/N $(-0.60)$, and TG-P/P $(-0.32)$. Moreover, EEG could directly affect EEG-C/SOC (0.39) and EEG-N/N (0.85), and TG could directly regulate TG-C/ SOC (0.56), TG-N/N (0.78), and TG-P/P (0.33).

We failed to find any direct or indirect effects of shelterbelt characteristics on GRSP features (Fig. 4), similar to the results summarized in Figs. 2 and 3. The effect of climatic factors on GRSP was indirect via their influence on soil properties, both PCA1 and PCA2. In the case of soil properties-PCA1 (mainly SOC, N, and AN), the coefficients for the indirect effects were -0.13 for EEG-N/N $(=0.29 \times-0.45), \quad-0.11$ for TG-C/SOC $(=0.29 \times$ $-0.39),-0.17$ for TG-N/N $(=0.29 \times-0.60),-0.09$ for TG-P/P $\quad(=0.29 \times-0.32), \quad 0.15$ for EEG $(=0.29 \times 0.52)$, and 0.17 for TG $(=0.29 \times 0.60)$. Similarly, in the case of soil properties-PCA2 (mainly pH, EC, and $\mathrm{AP}$ ), the coefficients for the indirect effects were 0.03 for $\mathrm{EEG}-\mathrm{N} / \mathrm{N}(=-0.19 \times-0.14), 0.04$ for TG-C/SOC $(=-0.19 \times-0.19), \quad 0.02$ for $\mathrm{TG}-\mathrm{N} / \mathrm{N} \quad(=-0.19 \times$ $-0.12)$, and 0.08 for EEG $(=-0.19 \times-0.40)$. Therefore, the indirect effect of climatic factors on GRSP from soil properties-PCA1 was $\sim 2-8$ times higher than that from soil properties-PCA2 (Fig. 4).

\section{Discussion}

\section{Greater GRSP-related SOC sequestration in the deep soil layer}

One of our main findings was that glomalin-related soil protein (GRSP) was more important in subsurface soil C sequestration than in surface soil $\mathrm{C}$ sequestration. Our data clearly show that GRSP decreased linearly from the 0-20 cm soil layer to the $80-100 \mathrm{~cm}$ layer, but its contribution to the soil organic carbon (SOC) pool was $\sim 1.2$ times higher in the deeper layers $(40-100 \mathrm{~cm})$ than in the surface soil $(0-40 \mathrm{~cm})$. Similar findings have been found in other studies. For example, farmland in Northeast China had lower levels of GRSP in deep soils than in surface soils, but $34-50 \%$ higher GRSP/SOC in deep soils (Wang et al. 2017a). Degraded grasslands had 18-35\% higher EEG/SOC and TG/SOC levels in the 5-20 cm layer than in the upper 0-5 cm layer (Zhang et al. 2015); citrus orchards had low GRSP contents at the soil surface because of low levels of soil $\beta$-glucosidase and carbohydrates (accumulated GRSP) and high levels of protease (decomposed GRSP) in the deep soil layer (Wu et al. 2012). Our findings (increased contribution of GRSP-C to SOC with increasing sampling depth) provide new evidence that microbially- 


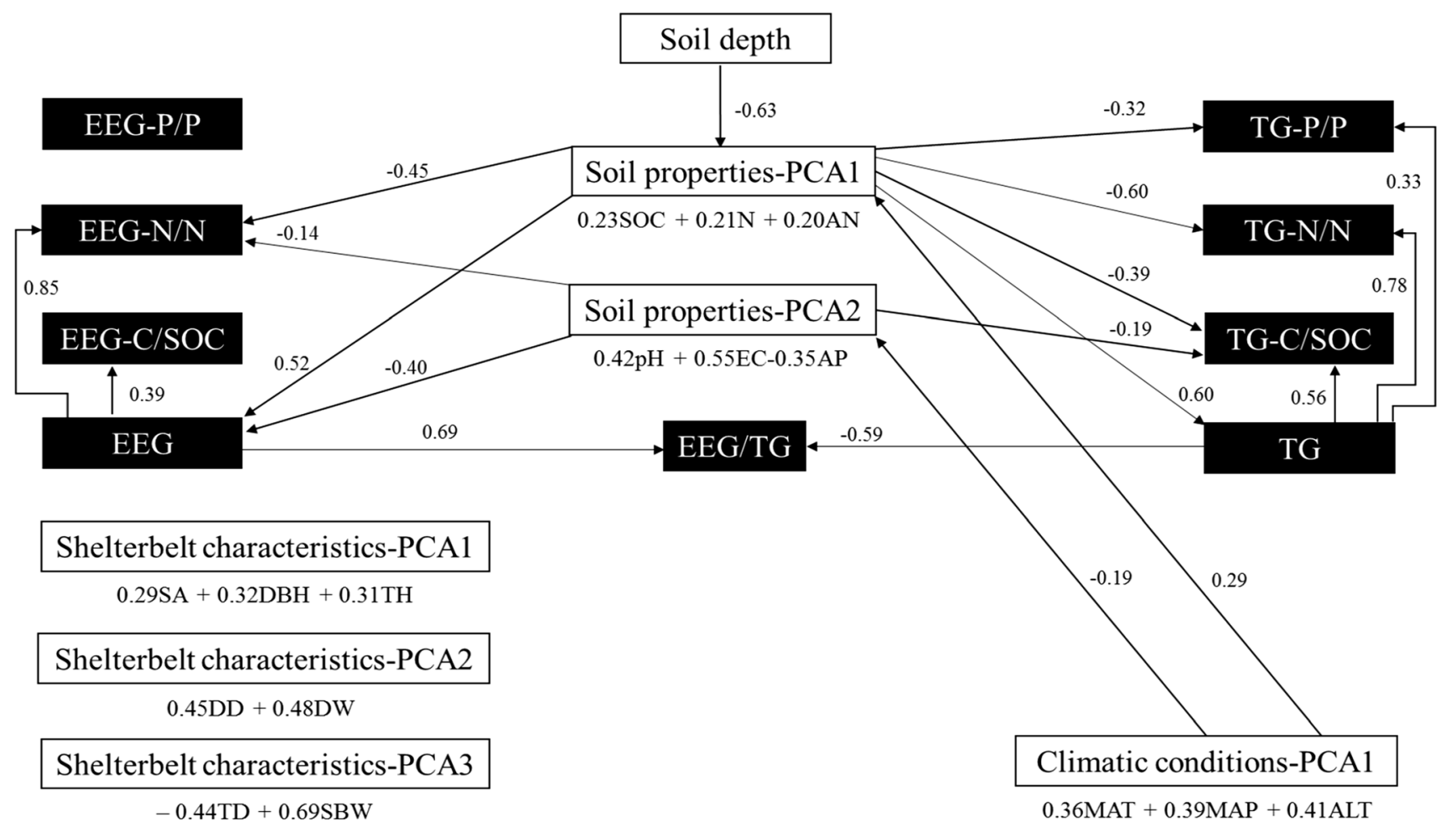

Fig. 4 SEM on the causal relations between GRSP features and soil depth, soil properties, climatic conditions, and shelterbelt characteristics. In this figure, the significant standard regression weights were added $(p<0.0001)$, while non-significant ones are not shown $(p>0.0001)$. Details of the regression weights and their statistics are in Table S4 and in the figure, the main contribution (top 2 or 3 highest contribution) of each principal component are also listed under the box. The following is the full equation for the principal components. Climatic conditions-PCA1: 0.36MAT + 0.39MAP + $0.41 \mathrm{ALT} ;$ Soil properties-PCA1: $-0.16 \mathrm{BD}+0.14 \mathrm{SW}-0.11 \mathrm{pH}+$ $0.02 \mathrm{EC}+0.23 \mathrm{SOC}+0.21 \mathrm{~N}+0.20 \mathrm{AN}+0.05 \mathrm{AP}+0.16 \mathrm{P}-0.10 \mathrm{~K}+$ 0.14AK; Soil properties-PCA2: $-0.17 \mathrm{BD}+0.10 \mathrm{SW}+0.42 \mathrm{pH}+0.55$ $\mathrm{EC}+0.06 \mathrm{SOC}+0.13 \mathrm{~N}+0.03 \mathrm{AN}-0.35 \mathrm{AP}-0.10 \mathrm{P}+0.003 \mathrm{~K}-0.15 \mathrm{AK}$

derived $\mathrm{C}$ enhances SOC sequestration in deep soil layers (Zhang et al. 2015). The greater contribution of GRSP to SOC sequestration may increase SOC stability in deep soil layers, owing to the greater stability of GRSP observed in different studies.

We also investigated glomalin-related $\mathrm{N}$ and $\mathrm{P}$ storage, and found that there were no significant differences between deep and surface soils in poplar shelterbelts. In general, EEG-N and EEG-P contributed 1-5\% of the total soil $\mathrm{N}$ and $\mathrm{P}$, while their amounts in TG accounted for $10-28 \%$ of their total in soils. In contrast to the results of this study, linear increases in glomalin/ $\mathrm{N}$ and glomalin/P (TG/P and TG/N in particular) as soil depth increases have been reported on farmland on the Songnen Plain (Wang et al. 2017a). This difference is possibly related to differences between trees and crops (mainly maize), i.e., the roots of trees are longer and can introduce more

Shelterbelt characteristics-PCA1: $0.29 \mathrm{SA}+0.32 \mathrm{DBH}+0.31 \mathrm{TH}-$ $0.16 \mathrm{TD}-0.09 \mathrm{SBW}+0.08 \mathrm{DSF}+0.12 \mathrm{DD}+0.07 \mathrm{DW} ; \quad$ Shelterbelt characteristics-PCA2: $-0.15 \mathrm{SA}-0.08 \mathrm{DBH}+0.03 \mathrm{TH}+0.27 \mathrm{TD}-$ $0.11 \mathrm{SBW}+0.07 \mathrm{DSF}+0.45 \mathrm{DD}+0.48 \mathrm{DW}$; Shelterbelt characteristics-PCA3: $-0.02 \mathrm{SA}-0.05 \mathrm{DBH}-0.02 \mathrm{TH}-0.44 \mathrm{TD}+0.69 \mathrm{SBW}-$ $0.32 \mathrm{DSF}+0.24 \mathrm{DD}+0.20 \mathrm{DW}$. SOC soil organic carbon, $N$ total nitrogen, $A N$ available $\mathrm{N}, P$ phosphorus, $A P$ available $\mathrm{P}, K$ potassium, $A K$ available $\mathrm{K}, E C$ electrical conductivity, $B D$ bulk density, $S W$ soil water, $M A T$ mean annual temperature, $M A P$ mean annual precipitation, $S A$ shelterbelt age, $T H$ tree height, $D B H$ diameter at breast height, $T D$ tree density, $S B W$ shelterbelt width, $D S F$ distance between shelterbelts and farmlands, $D D$ ditch depth, $D W$ ditch width, $A L T$ altitude

arbuscular mycorrhizal fungi and microbial taxa into deep soil layers. Deep soil nutrient depletion has been observed in Chinese forests (Wang et al. 2014b), Amazonian forests (Nepstad et al. 1994), areas of grassland reforestation (Chapela et al. 2001), and croplands (Johnson et al. 2011). GRSP-mediated increases in nutrients in deep soil layers should be considered in future soil management because of stability during nutrient release (Wright and Upadhyaya 1996) and the importance of fresh organic $C$ for microbial priming (Fontaine et al. 2007).

\section{Soil properties, climatic conditions, rather than shelterbelt characteristics as predictors of GRSP variation}

An understanding of the regulation of GRSP accumulation in soils is vital for the rehabilitation of GRSP-related 
degraded soils. Numerous studies have suggested that environmental factors, e.g., climatic conditions, plant diversity, soil properties, atmospheric $\mathrm{CO}_{2}$, and land-use changes can cause differences in GRSP levels (Hammer and Rillig 2011; Fokom et al. 2012; Wang et al. 2018b). Various statistical methods, i.e., redundancy analysis (RDA), principal component analysis (PCA), and structural equation modelling (SEM), were applied in the current study to analyze the causal relationships to explain the observed patterns (Eisenhauer et al. 2015).

Using these methods, we found that soil properties (SOC, N, AN, P, AP, pH, and EC) were the most important factors regulating GRSP features, and also determined their differences between surface and deep soils. Many studies have reported that GRSP content is negatively correlated with $\mathrm{pH}$ and EC (Wang et al. 2014a), and positively correlated with SOC (Wang et al. 2015), N (Rillig et al. 2003), AN (He et al. 2011), P (Gispert et al. 2013), and AP (Guo et al. 2012), without detailed descriptions of the differences between surface and deep soils. Singh et al. (2016) found similar associations between GRSP and SOC, $\mathrm{pH}, \mathrm{N}, \mathrm{P}$, and AP as in this study, while GRSP was not related to AN or EC on the Indo-Gangetic Plain $(0-15 \mathrm{~cm})$. This difference is possibly related to soil depth; in the present study, significant relationships between GRSP and EC and AP were mainly found in the surface soil layers, while a relationship between GRSP and AN was observed in the deep soil layers. SOC played a more important role in determining GRSP variation in the deeper soil layers $(61.9 \%)$ than in the surface layers $(56.7 \%)$, whereas $\mathrm{N}$ showed more variation in the surface layers (4.7\%) than in the deeper layers (1.2\%) (Table 4). Unlike poplar glomalin, farmland glomalin is regulated by soil nutrients (mainly SOC and $\mathrm{N}$ ) in surface soils, while physiochemical properties (e.g., pH) regulate glomalin in deep soils (Wang et al. 2017a), indicating that GRSP regulation by soil properties should depend on above-ground vegetation. In contrast to shallow-rooted crops, afforestation causes an important C sink to develop in deep soil layers (Jobbágy and Jackson 2000; Hooker and Compton 2003; Harrison et al. 2011), so different glomalin responses to soil nutrients should be included in vertical SOC sequestration studies.

The second most important factor in GRSP regulation was climatic conditions, and our findings indicate that climatic regulation can extend as deep as $1-\mathrm{m}$ in poplar forests. On the farmlands of northeastern China, stronger climatic regulation of GRSP has been found in deep soils than in surface soils (Wang et al. 2017a). GRSP contents decrease under high temperature (Rillig et al. 2002), but increase in seagrass meadow sediments with a high mean annual precipitation (MAP) during the wet season (Adame et al. 2012). Our findings are similar to these results. The climate at the study sites was characterized by a range of mean annual temperature (MAT) $\left(2.9-4.4{ }^{\circ} \mathrm{C}\right)$, MAP (421-481 mm), and altitudes (146.7-381.3 m) (Table 1), and we found that MAT in the surface soils and MAP in the deep soils differentially regulated GRSP features (Table 4; Fig. 3). Therefore, climatic regulation of GRSP accumulation in soils and differences between surface and deep soils should be investigated in future studies, particularly under the scenario of the greatest possible climatic changes in northeastern China compared with other regions.

The shelterbelt characteristics evaluated in this study had negligible effects on GRSP features, i.e., their specific effects only explained $<5 \%$ of GRSP variation, and both RDA variation partitioning (Fig. 2) and SEM (Fig. 4) cross-confirmed this negligible effect. We have investigated most shelterbelt characteristics in this paper and parameters included tree size (height, DBH) and age, and community characteristics (tree density and shelterbelt width), as well as ditch width, depth, and distance to neighbouring farmlands. These latter parameters are particularly important for farmland productivity and in preventing nutrient and water losses (Wang et al. 2017b). Both the RDA ordination and SEM analysis found insignificant effects on GRSP features (except for ditch width, as shown in the conditional term effects in the RDA ordination). Therefore, compared with soil properties and climatic conditions, tree size, community features, and shelterbelt characteristics had very little influence on GRSP variation. Previous studies have found that mixed primary forests have a 2.35-2.56-fold higher content of GRSP than plantations or farmlands (Wang et al. 2015), and plant richness is positively related to GRSP accumulation on the Tibetan Plateau (Li et al. 2015). In urban areas, stand characteristics, including tree size, community features, and compositional traits, account for $11 \%$ of the variation in glomalin, which is much lower than soil properties (Wang et al. 2018b). Therefore, more parameters related to compositional traits as well as land-use alterations, rather than individual sizes and community features, should be investigated concerning the regulation of soil GRSP accumulation in forests.

Furthermore, poplar forests have critical importance owing to its large afforestation area (Wu and Wang 2016) and the fast-growing characteristics for functional protections (Zhao 2002; Wu et al. 2018; Yang et al. 2018a, b). The growth of poplar could change soil biota (Wu and Wang 2016), soil enzyme and microbial biomass ( $\mathrm{Li}$ et al. 2018), soil carbon and nutrient (Wu et al. 2018, 2019) and is apt to damage from extreme climates (Yang et al. 2018a, b). Underground soil fungi-related changes reported in this paper indicates that GRSP in deep soil could response to climate changes; In the future, further steps for intensive management, such as fungus fertilizer application 
(Xia et al. 2018), could be used to improve the growth of poplar forests.

\section{Conclusions}

GRSP exhibited significant vertical variations in its contents, GRSP-C/SOC, GRSP-nutrient/total nutrient, and EEG/TG. Although GRSP accumulation was lower in the deeper soil layers than in the surface layers, its contribution to soil organic carbon storage was higher in the deeper soils. However, its contribution to soil nutrient levels was similar between surface and deep soils. Soil properties were the main factors responsible for this GRSP variation (ca. $45 \%$ for the specific effect) followed by local climatic conditions (ca. 20\% for the specific effect), while shelterbelt characteristics had a negligible effect $(<5 \%)$. Our findings highlight the factors that affect GRSP accumulation and may be useful for GRSP-mediated soil management and precise evaluation of GRSP importance in forests in northeastern China.

\section{Compliance with ethical standards}

Conflict of interest No potential conflict of interest was reported by the authors.

Open Access This article is distributed under the terms of the Creative Commons Attribution 4.0 International License (http://crea tivecommons.org/licenses/by/4.0/), which permits unrestricted use, distribution, and reproduction in any medium, provided you give appropriate credit to the original author(s) and the source, provide a link to the Creative Commons license, and indicate if changes were made.

\section{References}

Adame MF, Wright SF, Grinham A, Lobb K, Reymond CE, Lovelock CE (2012) Terrestrial-marine connectivity: patterns of terrestrial soil carbon deposition in coastal sediments determined by analysis of glomalin related soil protein. Limnol Oceanogr 57:1492-1502

Bao SD (2000) Soil and agricultural chemistry analysis. China Agriculture Press, Beijing

Chapela IH, Osher LJ, Horton TR, Henn MR (2001) Ectomycorrhizal fungi introduced with exotic pine plantations induce soil carbon depletion. Soil Biol Biochem 33:1733-1740

Deng RX, Zhang SW, Li Y (2009) Protective effects of farmland shelterbelts in Northeast China: a field scale analysis. Chin J Ecol 28:1756-1762

Eisenhauer N, Bowker MA, Grace JB, Powell JR (2015) From patterns to causal understanding: structural equation modeling (SEM) in soil ecology. Pedobiologia 58:65-72

Fokom R, Adamou S, Teugwa MC, Boyogueno ADB, Nana WL, Ngonkeu MEL, Tchameni NS, Nwaga S, Ndzomo GS, Zollo PHA (2012) Glomalin related soil protein, carbon, nitrogen and soil aggregate stability as affected by land use variation in the humid forest zone of south Cameroon. Soil Tillage Res 120:69-75

Fontaine S, Barot S, Barré P, Bdioui N, Mary B, Rumpel C (2007) Stability of organic carbon in deep soil layers controlled by fresh carbon supply. Nature 450:277

Ge XM, Deng SP, Zhu L, Li Y, Jia ZY, Tian Y, Tang LZ (2018) Response of nitrogen mineralization dynamics and biochemical properties to litter amendments to soils of a poplar plantation. J For Res 29:915-924

Gillespie AW, Farrell RE, Walley FL, Ross AR, Leinweber P, Eckhardt KU, Regier TZ, Blyth RI (2011) Glomalin-related soil protein contains non-mycorrhizal-related heat-stable proteins, lipids and humic materials. Soil Biol Biochem 43:766-777

Gispert M, Emran M, Pardini G, Doni S, Ceccanti B (2013) The impact of land management and abandonment on soil enzymatic activity, glomalin content and aggregate stability. Geoderma 202:51-61

Guo HJ, He XL, Li YP (2012) Spatial distribution of arbuscular mycorrhiza and glomalin in the rhizosphere of Caragana korshinskii Kom. in the Otindag sandy land, China. Afr J Microbiol Res 6:5745-5753

Hammer EC, Rillig MC (2011) The influence of different stresses on glomalin levels in an arbuscular mycorrhizal fungus-salinity increases glomalin content. PLoS ONE 6:e28426

Harrison RB, Footen PW, Strahm BD (2011) Deep soil horizons: contribution and importance to soil carbon pools and in assessing whole-ecosystem response to management and global change. For Sci 57:67-76

He X, Yang J, Zhao L (2011) Spatial distribution of arbuscular mycorrhizal fungi in Salix psammophila root-zone soil in Inner Mongolia desert. Acta Ecol Sin 31:2159-2168

Hooker TD, Compton JE (2003) Forest ecosystem carbon and nitrogen accumulation during the first century after agricultural abandonment. Ecol Appl 13:299-313

Janos DP, Garamszegi S, Beltran B (2008) Glomalin extraction and measurement. Soil Biol Biochem 40:728-739

Jha KK (2018) Biomass production and carbon balance in two hybrid poplar (Populus euramericana) plantations raised with and without agriculture in southern France. J For Res 29:1689-1701

Jia X, Zhao YH, Liu T, Huang SP, Chang YF (2016) Elevated CO2 increases glomalin-related soil protein (GRSP) in the rhizosphere of Robinia pseudoacacia L. seedlings in Pb-and Cd-contaminated soils. Environ Pollut 218:349-357

Jobbágy EG, Jackson RB (2000) The vertical distribution of soil organic carbon and its relation to climate and vegetation. Ecol Appl 10:423-436

Johnson JM, Archer DW, Weyers SL, Barbour NW (2011) Do mitigation strategies reduce global warming potential in the northern U.S. corn belt? J Environ Qual 40:1551-1559

Li X, Zhang J, Gai J, Cai X, Christie P, Li X (2015) Contribution of arbuscular mycorrhizal fungi of sedges to soil aggregation along an altitudinal alpine grassland gradient on the Tibetan Plateau. Environ Microbiol 17:2841-2857

Li Y, Zhang L, Fang S, Tian Y, Guo J (2018) Variation of soil enzyme activity and microbial biomass in poplar plantations of different genotypes and stem spacings. J For Res 29:963-972

Nepstad DC, Carvalho CRD, Davidson EA, Jipp PH, Lefebvre PA, Negreiros GH, Silva EDD, Stone TA, Trumbore SE, Vieira S (1994) The role of deep roots in the hydrological and carbon cycles of Amazonian forests and pastures. Nature 372:666-669

Rillig MC, Wright SF, Shaw MR, Field CB (2002) Artificial climate warming positively affects arbuscular mycorrhizae but decreases soil aggregate water stability in an annual grassland. Oikos 97:52-58 
Rillig MC, Ramsey PW, Morris S, Paul EA (2003) Glomalin, an arbuscular-mycorrhizal fungal soil protein, responds to land-use change. Plant Soil 253:293-299

Singh AK, Rai A, Singh N (2016) Effect of long term land use systems on fractions of glomalin and soil organic carbon in the Indo-Gangetic plain. Geoderma 277:41-50

Wang WJ, Qiu L, Zu YG, Su DX, An J, Wang HY, Zheng GY, Sun W, Chen XQ (2011) Changes in soil organic carbon, nitrogen, $\mathrm{pH}$ and bulk density with the development of larch (Larix gmelinii) plantations in China. Glob Change Biol 17:2657-2676

Wang Q, Wu Y, Wang WJ, Zhong ZL, Pei ZX, Ren J, Wang HM, Zu YG (2014a) Spatial variations in concentration, compositions of Glomalin Related Soil Protein in poplar plantations in Northeastern China, and possible relations with soil physicochemical properties. Sci World J 2014:13

Wang WJ, Wang HM, Zu YG (2014b) Temporal changes in SOM, N, $\mathrm{P}, \mathrm{K}$, and their stoichiometric ratios during reforestation in China and interactions with soil depths: importance of deep-layer soil and management implications. For Ecol Manag 325:8-17

Wang Q, Wang WJ, He XY, Zhang WT, Song KS, Han SJ (2015) Role and variation of the amount and composition of glomalin in soil properties in farmland and adjacent plantations with reference to a primary forest in North-Eastern China. PLoS ONE 10:e0139623

Wang Q, Wang WJ, He XY, Zheng QF, Wang HM, Wu Y, Zhong ZL (2017a) Changes in soil properties, X-ray-mineral diffractions and infrared-functional groups in bulk soil and fractions following afforestation of farmland, Northeast China. Sci Rep $7: 12829$

Wang WJ, Wang HM, Wang Q, Wu Y, Zhong ZL, Pei ZX (2017b) Differences in soil characteristics between poplar shelterbelt forests and farmland in Songnen Plain. Science Publisher, Beijing

Wang WJ, Zhong ZL, Wang Q, Wang HM, Fu YJ, He XY (2017c) Glomalin contributed more to carbon, nutrients in deeper soils, and differently associated with climates and soil properties in vertical profiles. Sci Rep 7:13003

Wang Q, Lu H, Chen J, Hong H, Liu J, Li J, Yan C (2018a) Spatial distribution of glomalin-related soil protein and its relationship with sediment carbon sequestration across a mangrove forest. Sci Total Environ 613-614:548-556

Wang WJ, Wang Q, Zhou W, Xiao L, Wang HM, He XY (2018b) Glomalin changes in urban-rural gradients and their possible associations with forest characteristics and soil properties in Harbin City, Northeastern China. J Environ Manag 224:225-234

Wright SF, Upadhyaya A (1996) Extraction of an abundant and unusal protein from soil and comparison with hyphal protein of arbuscular mycorrhizal fungi. Soil Sci 161:575-586

Wright SF, Upadhyaya A (1998) A survey of soils for aggregate stability and glomalin, a glycoprotein produced by hyphae of arbuscular mycorrhizal fungi. Plant Soil 198:97-107
Wright SF, Franke-Snyder M, Morton JB, Upadhyaya A (1996) Timecourse study and partial characterization of a protein on hyphae of arbuscular mycorrhizal fungi during active colonization of roots. Plant Soil 181:193-203

Wu Y, Wang WJ (2016) Poplar forests in NE China and possible influences on soil properties: ecological importance and sustainable development. In: Madeline V. Desmond (ed) Poplars and willows. Nova Science Publishers Inc, Hauppauge, pp 1-28

Wu QS, He XH, Zou YN, He KP, Sun YH, Cao MQ (2012) Spatial distribution of glomalin-related soil protein and its relationships with root mycorrhization, soil aggregates, carbohydrates, activity of protease and $\beta$-glucosidase in the rhizosphere of Citrus unshiu. Soil Biol Biochem 45:181-183

Wu Y, Wang WJ, Wang Q, Zhong ZL, Pei ZX, Wang HM, Yao YL (2018) Impact of poplar shelterbelt plantations on surface soil properties in northeastern China. Can J For Res 48:559-567

Wu Y, Wang Q, Wang H, Wang W, Han S (2019) Shelterbelt poplar forests induced soil changes in deep soil profiles and climates contributed their inter-site variations in dryland regions, Northeastern China. Front Plant Sci 10:e220

Xia X, Gao K, Xing X, Yang R, Zhang S, Du Z, Guo J, Liu X (2018) A recommended rate for application of Chaetomium globosum ND35 fungus fertilizer on poplar plantations in China. J For Res 29:933-941

Yang Y, He C, Huang L, Ban Y, Tang M (2017) The effects of arbuscular mycorrhizal fungi on glomalin-related soil protein distribution, aggregate stability and their relationships with soil properties at different soil depths in lead-zinc contaminated area. PLoS ONE 12:e0182264

Yang C, Peng J, Li X, Liang D, Yang Z, Zhang Y (2018a) The mechanism underlying overwintering death in poplar: the cumulative effect of effective freeze-thaw damage. J For Res. https://doi.org/10.1007/s11676-018-0828-x

Yang BL, Zhang WW, Xu HM, Wang SJ, Xu X, Fan H, Chen HYH, Ruan HH (2018b) Effects of soil fauna on leaf litter decomposition under different land uses in eastern coast of China. J For Res 29:973-982

Zhang J, Tang XL, He XH, Liu JX (2015) Glomalin-related soil protein responses to elevated $\mathrm{CO}_{2}$ and nitrogen addition in a subtropical forest: potential consequences for soil carbon accumulation. Soil Biol Biochem 83:142-149

Zhao YS (2002) Study on specifications of farmland shelterbelt net in Northeastern Plain of China. J For Res 13:289-293

Publisher's Note Springer Nature remains neutral with regard to jurisdictional claims in published maps and institutional affiliations. 